\title{
A KONDUKTÍV NEVELÉS CÉL- ÉS HATÁSRENDSZERE, VAGYIS AZ ORTOFUNKCIÓ KIALAKÍTÁSÁNAK FOLYAMATA
}

\author{
Szerzők:
}

Horváthné Kállay Zsófia

Semmelweis Egyetem (Magyarország)

Pető András Kar

Első szerző e-mail címe:

kallayzsofia@freemail.hu

\section{Lektorok:}

Horváthné Kállay Zsófia (2018): A konduktív nevelés cél- és hatásrendszere, vagyis az ortofunkció kialakításának folyamata. Különleges Bánásmód, IV. évf. 2018/3. szám, 73-92. DOI 10.18458/KB.2018.3.73

\begin{abstract}
Absztrakt
A tanulmány célja bemutatni a konduktiv nevelés helyét és szükségességét a mozgássérüléssel élők nevelésében, oktatásában és fejlesztésében. A konduktív nevelés elsösorban a központi idegrendszeri sérültek életminöségének javitását tüzte ki céljául. Ehhez az elmúlt 70 évben kialakitotta a sajátos hatásrendszerét, ami eredményességét garantálja. A konduktiv nevelés emberképe holisztikus, mely a nevelési folyamat összetettségében is megmutatkozik. A rehabilitációt a pedagógia oldaláról közelíti meg, ezért tanulásnak és újratanulásnak tartja, mely a napirend minden percében érvényesül.

Jelen tanulmány egy összetett elméleti kutatás részeredményeként a konduktív nevelés célés hatásrendszerének összefüggéseit elemzi, a konduktiv nevelés magyar nyelvü szakirodalmán keresztül. Az elemzés során a konduktív nevelés tényezőinek azonositására és különválasztására, müködésük elemezésére, törvényszerüségeinek feltárására törekedtünk, mely lehetöséget biztosit a konduktiv nevelés elvi-elméleti modellezésére. A tanulmányban külön fejezetben vizsgáljuk az ortofunkció, diszfunkció szavak jelentését, mert mind a célmeghatározásra, mind pedig hatásrendszerre befolyással bír.
\end{abstract}

Kulcsszavak: konduktív nevelés, ortofunkció, diszfunkció, hatásrendszer, mozgássérülés, esélyegyenlőség, pedagógiai rehabilitáció

Diszciplina: pedagógia, pszichológia, orvostudomány, filozófia

\begin{abstract}
This study is aimed to introduce the position and the necessity of conductive education in the education, instruction and development of persons with motor disabilities. The primary aim of conductive education is to improve the quality of life of individuals living with disabilities of central nervous origin. For this purpose a specific effect system has been developed in the past 70 years which guarantees the efficiency of the method. Its concept of humankind is holistic which is reflected also by the complexity of the education process. Rehabilitation is approached from the aspect of pedagogy, thus it is seen as learning and relearning and this is manifested in every minute of the daily routine.

In the present study the interrelations within the goal and effect system of conductive education are analysed through the specialist literature of conductive education written in
\end{abstract}


Hungarian as part of a complex theoretical research. During the analysis the author aspired to identify and separate the factors of conductive education, to analyse their functioning and to explore the underlying principles, which offers the opportunity for theoretical-academic modelling.

The meaning of the terms orthofunction and dysfunction is examined in a separate chapter of the study with regard to their impact on target setting and the effect system.

Keywords: conductive education, orthofunction, dysfunction, effect system, motor disability, equal opportunities, pedagogical rehabilitation

Disciplines: pedagogy, psychology, medicine, philosophy

\section{Bevezetés}

A tanulmány megírását az vezette, hogy ismertessünk egy olyan nevelési rendszert, mely nem a tipikusan fejlődő gyermekek és felnőttek nevelésével, oktatásával foglalkozik, hanem olyanokéval, akik a hagyományos nevelési rendszerben előzetes felkészítés, a társszakmák közötti szoros együttmüködés nélkül legtöbbször nehezen teljesítenek. A hagyományos nevelési rendszerben ugyanis sokszor nincs lehetőség arra, hogy az egyéni képességeknek megfelelő, adekvát tanítási eljárásokat alkalmazzanak (Réthy, 2002). A többségi nevelési rendszerben a nevelés korlátaiként elsősorban a biológiai-fiziológiai, a szociokulturális korlátok jelennek meg. Bábosik István (1999) és Mihály Ottó (1998) is megfogalmazza, hogy esetükben a nevelés folyamatát, a folyamat tervezhetőségét a külső és belső feltételek megváltozása megzavarhatja, az egyéni bánásmód elvének alkalmazására még erőteljesebben van szükség. A sajátos nevelési igényü (SNI) tanulók nevelésének és oktatásának lehetősége az utóbbi évtizedekben jelentős fejlődésen ment keresztül. Az integráció és az inklúzió fogalma előtérbe került, a törvényi változások is támogatják az érintetteket. Ezeknek a törekvéseknek köszönhetően a társadalmi elfogadás változik, egyre inkább az SNI gyermekek integrációját hozza.

Mégis az általános nevelési és oktatási rendszerek az integrációs törekvések mellett továbbra is a tipikus fejlődést mutató gyermekek nevelésére fókuszálnak. A mai gyakorlat szerint föként az enyhébb fokban sérültek tudják a többségi iskolában, integrált nevelés keretében megkezdeni tanulmányaikat. Az integráció megköveteli a fogyatékos gyermek alkalmazkodását a hagyományos iskolarendszerhez, éppen ezért az utóbbi időben az integráció alternatívái is megjelentek (Schüttler, 2002).

Az idegrendszeri sérült mozgássérültek részére - akiket kezdetben „gyógyíthatatlannak”, „képezhetetlennek” tartottak - mára számos módszer, terápia áll rendelkezésre. Ezek közül az egyik talán legösszetettebbnek a konduktív nevelés mondható, mely jeln elemzés tárgya.

Arra kerestük a választ, melyek a konduktív nevelés hazai szakirodalmában meghatározott, a konduktív nevelési gyakorlatot ténylegesen vezérlő nevelési célok? Mely nevelési tényezők biztosítják a célok elérését? Melyek a konduktív nevelés specifikus tényezői, módszerei? A mozgássérülésből adódó jellemváltozás milyen hatásegyüttesekkel ellensúlyozhatóak? A központi idegrendszeri sérültek neveléséhez, oktatásához milyen feltételeket tart szükségesnek? Hogyan történik a nevelési folyamat irányítása? Hogyan készíti elő a konduktív nevelés a többségi intézményekbe való integrációjukat?

A tanulmány elején ismertetésre kerül a kutatás elméleti kerete, az elemzéshez használt szempontrendszer. A következőkben áttekintjük, hogy a központi idegrendszer sérülése, hogyan hat a mindennapi élettevékenységek kivitelezésére. Ebből kiindulva a leíró, elemző 
részben mutatunk rá azoknak az összefüggéseknek egy részére, amelyek a konduktív nevelés összetettségét indokolják, a napirendi felépítését, a benne szereplö tevékenységek rendszerét befolyásolják. Ebben a részben kitérünk az ortofunkció, diszfunkció, ortomotorium és diszmotorium szakirodalmi meghatározására, melyek értelmezése szükséges a célok és a nevelési hatásszervezés megértéséhez.

Az ilyen és ehhez hasonló kutatási eredmények biztosíthatják az egyes nevelési rendszerek eredményes müködésének elméleti hátterét, eligazodási alapot biztosítanak, ami az elmélet és a gyakorlat együttmüködését és eredményességét nagymértékben meghatározza.

\section{Értelmezési keret}

Pető András az írásaiban (Pető, 1953, 1955) a személyiség holisztikus megközelítését hangsúlyozza és a konduktív nevelést a pedagógia, gyógypedagógia és az orvostudomány metszetében helyezte el. Mindezek ismeretében jelen vizsgálódáshoz értelmezési keretként a Bábosik István-féle (2004) nevelési modellt, a konduktív pedagógiát és rehabilitációt, azon belül is a pedagógiai rehabilitáció fogalomkörét jelöljük meg.

\section{Módszer}

A konduktív nevelési koncepció bemutatása során kitérek a konduktív nevelés céljaira, a nevelésben résztvevők körére, sajátosságaikra, a nevelési folyamatfelfogásra, a hatásszervezésre és mindezek összefüggéseire.

1945-2014 között négy korszak, meghatározott szempontok szerinti összehasonlítása során az azonosságok, különbözőségek vagy akár ellentétek felismerésére, beazonosítására, értelmezésére törekedtünk. A konduktív nevelés történeti szakaszolásához dr. Hári Mária történeti könyvében (Hári, 1997) ismertetett négy jól elkülöníthető időszakot vettük alapul.

Az adatgyüjtés a kritériumokra utaló kulcsmondatok megkereséséből és kiemeléséből állt a konduktív nevelés szakirodalmából. Az így kapott strukturált szövegek az eredeti dokumentumok szempontrendszer szerinti vetületének tekinthetők, melyek tartalmazzák az elemzés számára érdekes, szükséges információkat. Az elemzés során a szövegekben felismert neveléselméleti szempontból értelmezhető kulcsfogalmakat kiemeltük és rendszereztük. Elemző módszerek segítségével - tartalomelemzés, analízis és szintézis, összehasonlítás, absztrahálás, általánosítás, indukció és dedukció - törekedtünk a gyakorlati müködés sajátosságait feltárni.

\section{A minta}

A mintát olyan, a kutatás szempontjából lényeges, releváns dokumentumok adják, melyek létrejöttükkor, valamilyen közvetlen kapcsolatban voltak a konduktív pedagógia elméletével és gyakorlatával, a konduktív nevelés céljainak, folyamatának, módszereinek, sajátosságainak ismertetését tartalmazzák. Ezek a dokumentumok az általánosítottság szintje alapján eredeti vagy összegző dokumentumok és többségében a konduktorképzés számára készültek. Megjelenési módjukat tekintve írásos szövegek.

Az elemzett korszakokat figyelembe véve az 1945-töl a konduktív nevelés kialakításában és továbbfejlesztésében résztvevő, a munkásságukat konduktív nevelésnek szentelö szakmailag is elismert magyar szakemberek, Magyarországon megjelent írásait vettem alapul, amelyek releváns információkkal szolgálnak a kutatni szánt témához. A dokumentumok körébe kizárólag a legfontosabb hazai munkák kerültek be. A kutatás a Hári Mária Kari Könyvtár és Forrásközpont gyüjteményeire támaszkodik. 


\section{A konduktív nevelés történetének rövid áttekintése}

A sajátos nevelési igényü gyermekek orvosi, pedagógiai és szociális rehabilitációs intézményrendszere mára számos lehetőséget nyújt a mozgássérült emberek rehabilitációjában. Ennek egyik területe a Pető András által létrehozott konduktív nevelés, ami elsősorban a központi idegrendszeri sérülés következtében mozgásában kihívásokkal küzdő emberek nevelését, fejlesztését és oktatását tüzte ki feladatául.

A gyakorlati nevelés tapasztalatai és a formáinak kialakulása, a nevelési folyamat során szerzett tapasztalatok lehetőséget biztosítanak a nevelés rendszerének, a nevelés törvényszerüségeinek feltárására, a nevelő hatások és nevelési eredmények közti összefüggések vizsgálatára. A nevelési gyakorlat formálódása, a konduktív nevelési modell kialakulása, az intézményes nevelés rendszerének fejlődésével együtt haladt.

Pető András 1947-től kapott lehetőséget a Bárczi Gusztáv vezette Állami Gyógypedagógiai Nevelőintézet épületében az akkoriban konduktiv mozgásterápiának nevezett eljárás hatékonyságának bebizonyítására, a Gyermekvédő Intézetből rendelkezésére bocsátott "gyógyíthatatlannak" tartott gyermekekkel. Ezt az Állami Gyógypedagógiai Nevelőintézet Kísérleti Mozgásterápiai Osztályának nevezték.

A helyszínt kinőve 1950-ben kezdte meg müködését az Országos Mozgásterápiai Intézet, ami az Állami Gyógypedagógiai Tanárképző Főiskola Mozgásterápiai Tanszéke és Gyakorlóterülete is volt egyben (Hári, 1997).

1963 óta, mint önálló nevelési koncepció - konduktív nevelés - majd, mint rendszer müködik a központi idegrendszeri sérülés következtében mozgássérült személyek pedagógiai habilitációjában, rehabilitációjában, a köznevelési rendszer részeként köznevelési feladatokat lát el. Jelenleg Budapesten a Semmelweis Egyetem Konduktív Pedagógiai Központja a konduktív nevelés centruma.

\section{Milyen az élet központi idegrendszeri sérüléssel?}

A központi idegrendszeri sérülés a tartás, izomtónus, a mozgáskoordináció és a tanulási képességek zavarát eredményezheti. A kialakult tünetek a tudomány jelen álláspontja szerint véglegesen nem gyógyíthatóak, de a mozgásfunkciók zavara fejlesztéssel, neveléssel csökkenthetőek. A központi idegrendszeri sérülés ezért a gyermeknek és a családjának az életére egyaránt hatással van: befolyásolja a mindennapi tevékenységeket, az életminőséget, a szocializációs folyamatokat, családi élet müködését. A gyermek képességeinek - motoros, kommunikációs, szociális, kognitív - fejlődése eltérő utat vesz társaiétól, az érzelmi és akarati funkciók módosulnak (Benczúr, 2000; Kullmann, 2006; Vekerdy-Nagy, 2010).

A központi idegrendszeri sérülés következtében mozgássérüléssel élök életminőségének jellemzőiről, az ezt meghatározó tényezőkröl számos könyvfejezetet és tanulmányt olvashatunk. Ezekből megtudjuk, hogy a szenzomotoros hátrányaik miatt a mozgássérült gyermekeknek jóval kevesebb lehetőségük van a tapasztalatszerzésre, mint a velük egykorú társaiknak. Jelentős lemaradással rendelkeznek kortársaikhoz képest. A hely- és helyzetváltoztatás nehezített, az önkiszolgálási tevékenységek kivitelezése nehézséget jelent. Gyakori a kézfunkció, a manipuláció, a tárgy- és eszközhasználat, a grafomotoros teljesítmény, illetve a verbális és nonverbális kommunikáció eltérő mértékü akadályozottsága. Gyakori a tanulási zavar, tanulási probléma, tanulásban akadályozottság, a motoros nehézségek, a percepciózavar, figyelemkoncentrációjuk eltérő. Ugyanazon korosztályon belül is különbség van a hozott ismeretek és a képességek tekintetében.

További jellemzőként említhető az eltérő testalkat, a különböző tartási rendellenességek, az ortopéd problémák. Gyakori a fáradékonyság. A fogfejlődési rendellenességek nehezítik a megfelelő hangképzést (Hári, 2000; Balogh és Kozma, 2000; Rosenbaum és tsai, 2007; Cans és tsai, 2007; Papavasiliou és Panteliodis, 2011). 


\section{Gondolatok az ortofunkcióról és a diszfunkcióról}

A konduktív nevelés cél- és hatásrendszerének megértéséhez szükségesnek látszik az ortofunkció, diszfunkció valamint az ortomotorium és a diszmotorium (motoros diszfunkció, motorikus diszfunkció) szavak konduktív nevelésben használt értelmezése.

A szakirodalomban az ortomotorium a körülményeknek megfelelö, optimális mozgáskészséget jelenti. Ez a mozgáskészség az idegrendszer megfelelő müködésétől függ és a környezethez való alkalmazkodást teszi lehetővé. A Képzés tananyaga, I. témacsoport, A kondukció alapjai jegyzet így fogalmaz: „Az ép mozgás /ortomotorium/ a megfelelő alkalmazkodás egy formája, a mindenkori körülményeknek leginkább megfelelő mozgáskészség, mely az idegrendszer megfelelő müködésének a függvénye (Képzés tananyaga, 1965, 7. o.)”. Hári Mária (1982) úgy fogalmazott, hogy akkor beszélhetünk ortomotoriumról, ha az összes akaratlagos cselekvés kialakult.

Az ortofunkció az előbbiekből adódóan a körülményeknek megfelelő cselekvéses alkalmazkodást, helyzetnek adekvát folyamatos cselekvést jelenti, mely alkalmazkodás az életben való folyamatos helytállást, az életben adódó feladatok megoldását, a társadalmi hasznosságot eredményezi. Az ortofunkció tulajdonképpen egy egész életen át tartó adaptációs-tanulási képessége az embernek (Képzés tananyaga, 1965; Hári és Ákos, 1971; Hári, 1982; Hári és tsai, 1991). „Az orthofunctio nagyon sokoldalú, az egész személyiséget érintő képesség arra, hogy az egyén a vele szemben támasztott biológiai (és társadalmi) követelményeket kielégítse (Hári és Ákos, 1971, 122. o.)”. Fontos szempontnak mutatkozik, hogy az ortofunkció nem azonos az ép mozgások összességével, hanem sokkal inkább a koordinált idegrendszeri müködés, összerendezés eredményeként megvalósuló célnak megfelelő, célt megvalósító mozgás (Hári, 1981; Örkényiné Deák, 1997).

A diszfunkció szó hiányra utal, az ortofunkció hiányára. A szakirodalomban olvasható meghatározások szerint a diszfunkció valamely funkció megváltozására, a funkciók dezintegrációjára, megváltozott koordinációra utal. Diszfunkció esetében a szervezet és a környezet kölcsönhatása összerendezési, szervezési zavarban nyilvánul meg. A diszfunkciós képtelen az életkor szerint teljesíthető követelmények kielégítésére, a legkülönbözöbb területeken a tőle várt adaptációra, az új feltételek szerinti tevékenység megtanulására, mert az általános adaptációs képessége csökkent, vagy megszünt. Mindezek hátterében a tanulási képesség eltérő volta áll (Képzés tananyaga, 1965; Hári és Ákos, 1971; Hári, 1982; Hári és tsai, 1991).

A motoros diszfunkció - motorikus diszfunkció, diszmotorium - müködés elváltozás, a ki nem fejlődött vagy leépült ortomotorium. A motoros diszfunkció az idegrendszer károsodása, nem megfelelő müködése eredményeképpen létrejövő lelassult, megváltozott, korlátozott gyermekkori fejlődés következménye. A motoros diszfunkció az ember cselekvéses alkalmazkodását befolyásolja, mely hátterében a tanulás módjának, útjának megváltozása áll (uo.).

Az alábbi táblázat a szakirodalom elemzése során gyüjtött adatok lényegkiemelő redukcióját tartalmazza az előbb említett fogalmakra vonatkozóan (lásd: 1. táblázat). 
3. táblázat: Az ortofunkció, ortomotorium, diszfunkció és motoros diszfunkció szavak szakirodalmi meghatározásai (forrás: Képzés tananyaga, 1965; Hári és Ákos, 1971;

Hári,1981; Hári, 1982; Hári és tsai, 1991, Örkényiné Deák, 1997; Balogh, 1998)

\begin{tabular}{|c|c|c|c|}
\hline ORTOFUNKCIÓ & ORTOMOTORIUM & DISZFUNKCIÓ & $\begin{array}{c}\text { DISZMOTORIUM } \\
\text { MOTOROS } \\
\text { /MOTORIKUS } \\
\text { DISZZUNKCIÓ } \\
\end{array}$ \\
\hline $\begin{array}{l}\text { megfelelö cselekvéses } \\
\text { alkalmazkodás, } \\
\text { az élet alkalmazkodási } \\
\text { reakcióinak sorozata, } \\
\text { az egyén személyes és } \\
\text { társadalmi körülményei- } \\
\text { ben való helytállása, } \\
\text { életfeladatokmegoldása, } \\
\text { körülményekhez alkal- } \\
\text { mazkodó mozgáslánco- } \\
\text { lat }\end{array}$ & $\begin{array}{l}\text { ha sikerül az összes } \\
\text { akaratlagos mozgás ki- } \\
\text { alakítása, } \\
\text { a megfelelő alkalmaz- } \\
\text { kodás egy formája, } \\
\text { a mindenkori körülmé- } \\
\text { nyeknek leginkább } \\
\text { megfelelő mozgás- } \\
\text { készség, } \\
\text { optimálisan megfelelő } \\
\text { mozgásképesség. }\end{array}$ & $\begin{array}{l}\text { ortofunkció hiánya, } \\
\text { megváltozott funkció, } \\
\text { megváltozott koordi- } \\
\text { náció, } \\
\text { a funkciók dezinteg- } \\
\text { rációja, } \\
\text { hibás koordinációból } \\
\text { származó funkcióza- } \\
\text { var, } \\
\text { a funkció folyama- } \\
\text { tának változása }\end{array}$ & $\begin{array}{l}\text { idegrendszeri elválto- } \\
\text { záson alapuló müködés } \\
\text { elváltozás, } \\
\text { a ki nem fejlődött vagy } \\
\text { leépült ortomotorium }\end{array}$ \\
\hline $\begin{array}{l}\text { helyes/megfelelö mükö- } \\
\text { dés, } \\
\text { célnak megfelelő moz- } \\
\text { gás, jó összerendezés }\end{array}$ & ép mozgás & $\begin{array}{l}\text { helytelen/nem meg- } \\
\text { felelö müködés a } \\
\text { mozgásdiszfunkciót, a } \\
\text { spazmust, a rigort s } \\
\text { mindazon tüneteket, } \\
\text { melyek a hiperaktív } \\
\text { gamma-rendszer mü- } \\
\text { ködése folytán létre- } \\
\text { jönnek, protézis, egyéb } \\
\text { segédeszköz alkalma- } \\
\text { zása sem javít, illetve } \\
\text { nem javít lényegesen } \\
\text { rajta }\end{array}$ & mozgássérülés \\
\hline $\begin{array}{l}\text { az egész személyiséget } \\
\text { érintő képesség, } \\
\text { az egész senzomoto- } \\
\text { rikus összmüködésre } \\
\text { vonatkozik, } \\
\text { szenzoros, motoros, } \\
\text { praxikus, gnosztikus és } \\
\text { kommunikációs } \\
\text { müködés komplex } \\
\text { együttese, koordinált } \\
\text { múködés }\end{array}$ & $\begin{array}{l}\text { az idegrendszer } \\
\text { „megfelelő müködé- } \\
\text { sén” alapszik, } \\
\text { a szenzomotorikus } \\
\text { összmüködés }\end{array}$ & $\begin{array}{l}\text { a szervezet és } \\
\text { környezet kölcsönha- } \\
\text { tásából származnak, } \\
\text { a fogyatékosság össze- } \\
\text { rendezési, szervezési } \\
\text { zavarban nyilvánul } \\
\text { meg, jobb összeren- } \\
\text { egy jóná } \\
\text { dezés mód tanulható, } \\
\text { tehát változás lehetsé- } \\
\text { ges }\end{array}$ & $\begin{array}{l}\text { idegrendszeri } \\
\text { elváltozáson alapszik, } \\
\text { idegrendszer károsodása } \\
\text { következtében, lelassult, } \\
\text { korlátozódott és eltor- } \\
\text { zult gyermekkori fejlő- } \\
\text { dés következménye, } \\
\text { az idegrendszer nem } \\
\text { „megfelelő müködésén” } \\
\text { alapszik }\end{array}$ \\
\hline
\end{tabular}

Azonosságként emelhetjük ki a négy kifejezésnél, hogy az idegrendszeri müködésen alapulnak, hatással vannak a szenzomotoros koordinációra, az egész személyiség fejlődésére, ezáltal az ember és a környezet kapcsolatát befolyásolják.

Különbségként a tanulási képességet, a környezethez való alkalmazkodás megvalósulási lehetőségét emelhetjük ki az ortofunkció és a diszfunkció meghatározásánál.

Összefoglalva az előbbieket, idézve Hári Máriát és társait, akik a következőképpen fogalmaznak: „A diszfunkció kifejezés azt a meggyőződést tükrözi, hogy a probléma nem statikus, helyi jellegü, a fogyatékosság összerendezési, szervezési zavarban nyilvánul meg, és egy jobb összerendezési mód tanulható, tehát változás lehetséges. A hagyományos szemlélet 
szerint az idegrendszeri károsodások visszafordíthatatlansága miatt az általuk okozott fogyatékosságok maradandóak. A diszfunkció a helytelen, az ortofunkció kifejezés a helyes müködést jelenti, és ez úgy értelmezhető, hogy az a személy, akinek strukturális károsodása következtében fogyatékossága van, ennek ellenére meg tud tanulni, meg tud találni egy helyes müködési stratégiát" (Hári és tsai, 1991, 10. o.).

A konduktív nevelés szakirodalmában az elöbbiek alapján rögzíthetjük, hogy az ortofunkció szó a célnak megfelelö müködésre, az ortomotorium szó a megfelelö, célirányos mozgásra, a diszfunkció szó a nem megfelelö müködésre és a motoros diszfunkció szó a nem rendeltetésszerü, a nem célirányos mozgásra, mozgássérülésre utal.

A továbbiakban szükségesnek mutatkozik az ortofunkciósság és az ortofunkció szavak megkülönböztetése is. Hári Mária megfogalmazását használva az „othofunkciósság kiegyensúlyozottságot, produktivitást, célokért küzdőképességet jelent. [...] A készenlét a problémamegoldásra, a spontenaitás, az élet- és munkamódszer személyiségvonás, ami a súlyos fogyatékosság, a struktúra változatlansága ellenére is fejleszthető" (Hári, 1990b, 8. o.). Az ortofunkciósság ebben az értelmezésben érdeklődést, a cél megvalósításának szándékát, a készenlétet jelenti.

Az ortofunkció és a diszfunkció ténye a személyiség fejlődésére is hatással bír (lásd: 2 . táblázat). Milyen is az ortofunkciós és a motoros diszfunkciós személyisége?

A diszfunkció következtében sérül a környezethez való adaptáció, mely adaptációs zavar az egész személyiség fejlődésére kihat, integratív funkciókárosodást eredményezve. A mozgássérülésből adódóan a tapasztalatszerzés késik, módja, mennyisége és minősége megváltozik, a tapasztalatszerzésre épülő tanulási folyamat módosul. Ez a folyamat a személyiség alakulására is kihatással bír.

Az ortofunkciós személyiség folyamatosan, dinamikusan fejlődik. Jellemző rá, hogy a vele szemben állított követelményeknek, akár biológiai, akár társadalmi szempontból eleget tud tenni, képes folyamatosan alkalmazkodni a változó feltételekhez, a környezetének elvárásaihoz, képes hasznossá válni, vagyis képes szocializálódni. Az ortofunkciós személyiség alkalmazkodó képességének fejlődése egész életen át tart, ez teszi képessé az életben való eligazodásra, illetve az akaratának érvényre juttatásában. Ezt a koncepció általános adaptációs-tanulási képességnek nevezi (Képzés tananyaga, 1965; Hári és Ákos, 1971).

Ahhoz, hogy egy személyiség diszfunkcióssá váljon, sorozatos kudarcnak kell érnie, a tapasztalatszerzés akadályozottságának kell fennállnia, mely az életkornak megfelelő biológiai és társadalmi elvárásoknak és szükségleteknek a kielégítését akadályozzák. Mindezek eredményeképpen a mozgássérült és a környezete közti kapcsolatok kialakításának lehetősége átalakul. A folyamatos kudarc, sikertelenség frusztrációt, dühöt, elkeseredést, bizalmatlanságot eredményez, az adaptációs-tanulási folyamat lelassulását, elakadását hozza. Ez vezet a személyiség megváltozásához. Kialakul az egocentrikusság, kisebbségi érzés (Képzés tananyaga, 1965; Hári és Ákos, 1971).

A diszfunkciós személy képtelen az életkor szerint teljesíthetö követelményeknek eleget tenni. Ennek oka, hogy nem tud az újonnan fellépö feltételekhez alkalmazkodni, mert az ehhez szükséges tevékenységek megtanulása nehezített. Ebben az esetben az általános adaptációs képesség csökkenéséről, megszünéséről vagy a tanulási képesség eltérőségéről beszélhetünk.

Motoros diszfunkciós (mozgássérült) személyiség esetében ez a tanulás módjának megváltozásában jelentkezik, mivel itt az elváltozás sohasem korlátozódik csak a mozgásszervekre, hanem idegrendszeri eredetü, kihat az észlelésre, az érzékelésre és a 
mozgásra, a beszédre, a testtartásra egyaránt. Motoros diszfunkciós személynél a cselekvéses alkalmazkodás sérül.

4. táblázat: Az ortofunkciós és diszfunkciós személyiség jellemzői és ebböl adódóan a motoros diszfunkciós személyiség sajátosságai (forrás: Képzés tananyaga, 1965; Hári és Ákos, 1971; Hári, 1982; Hári és tsai, 1991, Örkényiné Deák, 1997; Balogh, 1998)

\begin{tabular}{|c|c|c|}
\hline $\begin{array}{l}\text { ORTOFUNKCIÓS } \\
\text { SZEMÉLYISÉG }\end{array}$ & $\begin{array}{l}\text { DISZFUNKCIÓS } \\
\text { SZEMÉLYISÉG }\end{array}$ & $\begin{array}{l}\text { MOTOROS } \\
\text { DISZIFUNKCIÓS } \\
\text { SZEMIÉLYISÉG }\end{array}$ \\
\hline $\begin{array}{l}\text { képes a vele szemben támasztott } \\
\text { biológiai és társadalmi köve- } \\
\text { telmények kielégítésére, } \\
\text { képes mások számára is } \\
\text { jelentőséggel bíró munka elvég- } \\
\text { zésére, } \\
\text { képes hasznossá válni (szociali- } \\
\text { zálódni), } \\
\text { mással is tud foglalkozni nemcsak } \\
\text { a saját problémájával, } \\
\text { alkalmazkodik a maga természe- } \\
\text { tes és társadalmi környezetéhez, } \\
\text { céljaikat sokféleképpen el tudják } \\
\text { érni }\end{array}$ & $\begin{array}{l}\text { képtelenség az életkor szerint } \\
\text { különben ältalánosan teljesíthető } \\
\text { összes követelmények kielégí- } \\
\text { tésére, } \\
\text { képtelenek a legkülönbözőbb } \\
\text { területeken a tölük várt adaptá- } \\
\text { cióra, } \\
\text { képtelenség az új feltételek } \\
\text { szerinti tevékenység megtanulá- } \\
\text { sára, } \\
\text { meg kell tanítani a céljai } \\
\text { elérésére }\end{array}$ & $\begin{array}{l}\text { a tanulás módja/lehetősége } \\
\text { változott meg }\end{array}$ \\
\hline $\begin{array}{l}\text { dinamikus, folyamatosan módo- } \\
\text { sítható rendeződés, } \\
\text { egész életen át tartó, mind } \\
\text { szélesebb körben képes } \\
\text { alkalmazkodni }\end{array}$ & $\begin{array}{l}\text { a probléma nem statikus, nem } \\
\text { helyi jellegú, megváltoztatható }\end{array}$ & $\begin{array}{l}\text { egész személyiséget érinti, } \\
\text { a mozgásszervi elváltozá- } \\
\text { sok, ha vannak másodlago- } \\
\text { sak, } \\
\text { sohasem korlátozódik a } \\
\text { mozgásszervekre, kihat a } \\
\text { motoriumra és a sensorium- } \\
\text { ra (cselekvés, érzékelés, } \\
\text { észlelés) egyaránt, }\end{array}$ \\
\hline $\begin{array}{l}\text { általános adaptációs-tanulási } \\
\text { képesség }\end{array}$ & $\begin{array}{l}\text { általános adaptációs képesség } \\
\text { csökkent vagy megszünt, } \\
\text { tanulási képesség eltérő }\end{array}$ & $\begin{array}{l}\text { cselekvéses alkalmazkodást } \\
\text { befolyásolja }\end{array}$ \\
\hline $\begin{array}{l}\text { következménye az élethez való } \\
\text { megfelelő alkalmazkodás, akarat } \\
\text { megvalósítása, az egyén egész } \\
\text { életen át tartó adaptációs fejlődése }\end{array}$ & \multicolumn{2}{|c|}{ az adaptációs-tanulási folyamat lelassulása, elakadása } \\
\hline
\end{tabular}

A fogalmak tisztázása azért is látszik lényegesnek a kutatás szempontjából, ugyanis attól függően mit tartunk problémának, hogyan értelmezzük, az befolyásolja a célkitüzést, ami meghatározza a célt megvalósító hatásrendszer megválasztását is. A konduktív nevelés ezeket alapul véve az ortofunkció kialakításánál az egész személyiség fejlesztését, a problémamegoldó tanulást, a cselekvés kognitív faktorait hangsúlyozza (Hári, 1990a). Hári és Ákos szerint: „A konduktív pedagógia nem egyéb, mint az orthofunctióssá nevelés, az egész dysfunctiós személyiség adaptív-tanulási fejlődését biztosító rendszer" (Hári és Ákos, 1971, 126. o.). 


\section{A konduktív nevelés célrendszere}

10. ábra: A konduktív nevelés célrendszere (forrás: a Szerzö)

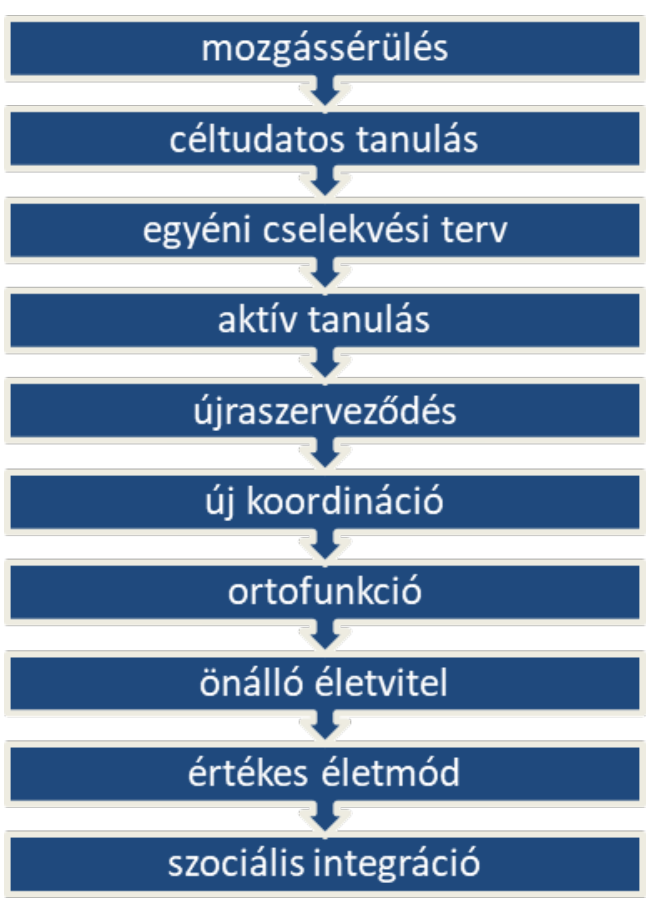

A nevelés minden társadalomban céltudatos tevékenység. A kiválasztott és elfogadott célok áthatják az egész nevelés rendszerét, annak minden komponensét, a nevelést és oktatást egyaránt (Kotschy, 2003). A célok mindig valamilyen embereszmény elérését célozzák meg. Ez az embereszmény ,az adott kor, társadalom, kultúra, jog- és szokásrendszer által meghatározott konstruktív nevelési értékek halmaza" (Búsi és Borosán, 2004, 7. o.). Báthory Zoltán (1997) és Mihály Ottó (1974) értelmezésében az érték, mindig az értékesnek tartott lényeg, a nevelési eszmény, míg a cél mindig ennek a lényegnek az elérése irányul.

A konduktív nevelési felfogás elfogadja a társadalom által meghatározott értékeket és az ennek megfelelő magatartás- és tevékenységformák kialakítását tűzte ki céljául, de figyelembe veszi a mozgássérülés következtében kialakult személyiségváltozást is. Ennek következtében kiemel bizonyos értékeket, melyek kialakítását domináns feladatának tartja.

A személyiség módosulás passzivitás, kisebbségi érzés, egocentrikusság, düh, agresszió, bizalmatlanság képében jelenik meg. A differenciált értékek ezek leépítését célozzák meg. Értékként jelenik meg a kezdeményezö képesség, a kötelesség- és feladattudat, az öntevékenység, a konstruktív aktivitás, a kitartás, a teherbírás, a pozitív beállitódás, a készenlét. Külön kiemeli a koncepció az ortofunkciós megoldásmódok megtanulását, mint értéket. Mindezek eredményeképpen a mozgássérült a társadalom hasznos, önálló és egyenértékü tagjává válhat (Mozgásterápiai Intézet és Tanszék Munkaközössége, 1957; Képzés tananyaga, 1965; Hári és Ákos, 1971; Hári, 1982; Hári és tsai, 1991; Balogh, 1998).

A konduktív nevelés a mozgássérülést nem betegségnek, hanem tapasztalatlanságnak tartja. A koncepció fő célkitüzése a tevékenységre való képesség, a feladatmegoldás módjainak megtanítása, a problémamegoldó- és a tanulási képességének kialakítása. A mozgássérült ember céljának, akaratának megvalósítása nehezítetté válik, aminek következtében kialakul nála az érdektelenség. Ez akár a közösségen belüli izoláltsághoz is vezethet.

A környezethez való alkalmazkodás akadályozottsága, a mozgássérült érzékelési és percepciós folyamatainak módosulását, a megismerési folyamat lelassulását, a tanulási folyamatának módosulását hozza. Ami alapesetben egy tevékenység kivitelezése során automatikusan megy végbe, a sérültnek arra is figyelnie kell.

Mindezeket alapul véve a konduktív nevelési folyamat első lépése a célképzés, a céltudatos tanulás kialakítása (lásd: 1 . ábra), mely célképzés tevékenységre indít, készenléti állapotot eredményez. A teória alapján az ember alapvető szükséglete a céljainak az elérése, a biológiai és társadalom felé támasztott követelmények kielégítése. A célképzés, majd a cél sikeres elérése a pozitív hozzáállás kialakulását segíti, az akarati tényezők és a figyelem fenntartását támogatják. 
A célok megfogalmazása azok elérésére serkent, a problémahelyzet megoldására, a cselekvés akarására. Ehhez egyéni cselekvési terv kidolgozására van szükség.

Az előbb említettek előfeltétele az intenció, vagyis a cselekvés belső képe, tervezete (a készenléti állapot), a célképzés, a megfelelő érzelmi és akarati funkciók, az érdeklődés és az érzelmi biztonság megléte.

Ezek együttese eredményezi az aktív tanulást. Az elképzelésben nem csak a fizikai aktivitást, hanem a célképzést, érdeklődést, tervezést is aktivitásnak tekinti. Az előbbiekből összefoglalva azt határozhatjuk meg, hogy ezek a tényezök elengedhetetlenek a mozgás akarásának kialakításához.

Az aktív tanulási folyamat eredményeképpen létrejött mozgás, azaz az intendált, céltudatos cselekedet támogatja a cél elérésének folyamatát, segíti a mozgás belső képének kialakulását, a mozgás újraszervezödését. Az új megtanult mozgást a koncepció új koordinációnak hívja.

Lényegesnek mutatkozik a nevelési folyamat szervezésének szempontjából, hogy az új koordinációt és az ortofunkciót megkülönbözteti egymástól a szakirodalom. Az új koordinációból megfelelő hatásszervezéssel alakul ki az ortofunkció. Az ortofunkciót abban különbezteti meg az új koordinációtól, hogy míg az új koordinációt, a „mozgást” csak a tanult helyzetekben tudja alkalmazni a sérült, addig ortofunkció esetében már bármilyen élethelyzetben, azaz a környezethez adaptálja a cselekedetet.

A kialakult célirányos mozgás segíti az akarat és az elvárások kielégítését, növeli az önbizalmat, a hasznosság, értékesség érzetét, sikerélményt biztosít és ezáltal folyamatos aktivitásra ösztönöz, hozzásegítve a mozgássérültet egy aktív, önálló, értékes életvezetési modell kialakításában. A konduktív nevelés legfontosabb céljának a társadalmi elfogadást tartja. A konduktív nevelés céltartalmát illetően kezdetben dominál az önfejlesztés, a nevelés közösségi szempontjai a folyamat lefolyása közben érvényesülnek, majd a fejlődés beindulásával a kétféle céltartalom együttes megvalósulása érvényesül.

A célrendszerben felvázolt célok egymással szoros összefüggésben jelennek meg a nevelési folyamatban, átfedés, kölcsönhatás van közöttük, a hatásszervezés szempontjából egységet képeznek, a napirendi tevékenységekben párhuzamosan jelennek meg. A nevelés, tanulás és a gyakorlás, alkalmazás folyamatos.

A célrendszer levezetése után szükséges meghatározni, mit is jelentenek az előbb felsorolt célok a hatásszervezés szempontjából (lásd: 2. ábra).

A konduktív nevelés elsődleges feladata az elözőekböl adódóan a mozgás akarásának kialakítása, azaz a személyiség motivációs, ösztönző sajátosságainak mozgósítása. Ehhez olyan, az életkornak megfelelő adaptív-tanulási fejlödés biztosítását, vagyis olyan tanulási helyzetek megteremtését kell biztosítani, melyek a környezethez való alkalmazkodást segítik. A folyamatot úgy kell megszervezni, hogy sikerélményt, mozgásörömöt és eredményélményt keltsen, segítse az intenció, az aktivitásra, cselekvésre kész állapot kialakulását 


\section{1. ábra: A konduktív nevelés céljai a hatásszervezés szempontjából (forrás: a Szerzö)}

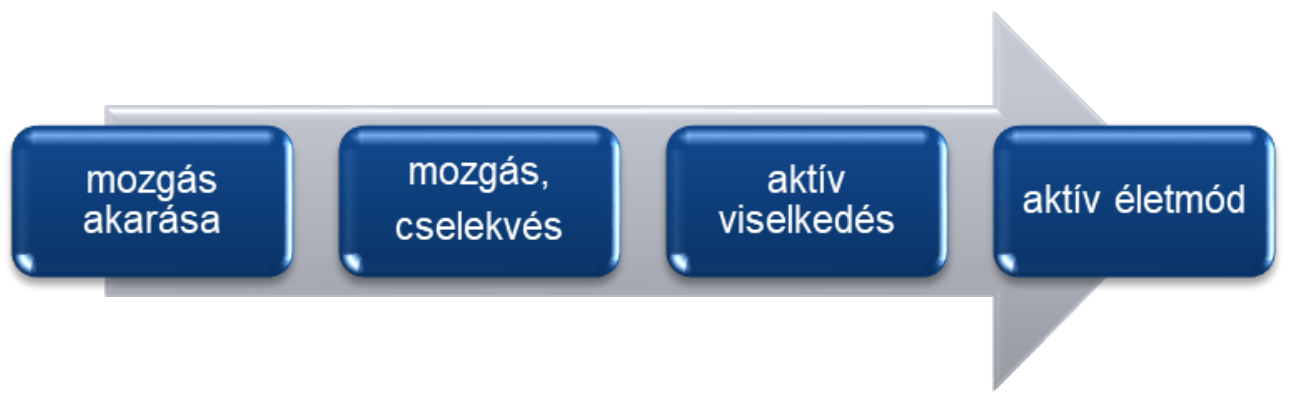

Következő lépésként feladat az aktív tanulási folyamat fenntartása, mely tanulás eredménye a mozgás, cselekedet újraszerveződése. Ehhez olyan komplex fejlesztés szükséges, melyben a holisztikus emberképből adódóan mind a mozgás, a beszéd, a kognitív funkciók, az érzelem, mind a szociális kapcsolatok egyidejü, egy személy általi fejlesztése valósul meg.

Ahhoz, hogy a megtanult mozgás, cselekedet ne egy megtanult, de céltalan mozgás legyen, a mozgássérültnek azt az élet minden helyzetében meg kell tanulnia alkalmaznia. A megfelelő biológiai szükségletek és társadalmi elvárások biztosítása ehhez elengedhetetlen feladatnak bizonyul. Ilyen élethelyzetek lehetnek a játék, a tanulás, az óvodai élet, az iskolai élet, a munkavégzés, az önellátási tevékenységek vagy akár a szabadidő hasznos eltöltése. Ezek az élethelyzetek mindamellett, hogy az aktív viselkedés létrejöttét támogatják, hatással vannak az ismeretek, jártasságok, készségek és képességek kialakulására is.

Végül feladata olyan életvezetési minták, modellek, meggyőzősek párhuzamos közvetítése, mely folyamatos, életen át tartó tanulást, és az ehhez szükséges aktív életmód fenntartását biztosítják.

A konduktív nevelés célrendszerében körvonalazódni látszik az "én" dimenziója, mely az egyéni képességeket, az egyéniséget emeli ki. Ennek legfontosabb része a motiváltság, az akarat, az érdeklődés kibontakoztatása, majd a tanulási folyamatban az egyéni megoldásmódok kialakítása. A koncepció a személyiség motivációs rendszerének fejlesztését tartja elsődlegesnek, melynek elemei az erőfeszítés, hősiesség képessége, siker és kudarc kezelésének képessége, önállóság, önfegyelem képessége, mely forrása az önbecsülés és emberi méltóság kialakulásának.

A célokban megjelenik a „társas dimenzió”. A szakirodalom elemzése során egyértelmüen kirajzolódott, hogy a közösségi nevelés a társadalomba való illesztés alapfeltételként jelenik meg. A koncepció azt mondja, hogy a mozgássérült gyermeknek is igénye van a közösségre, a közösségből való kiemelése gyakran kudarcélményt kelt benne. A közösség motiváló erő a csoporttag számára a képességei kibontakoztatására, önmaga megismerésére és egyben a társadalmi alkalmazkodás megtanulásának, a közösségi élet, a kreatív magatartás, a kommunikáció módjai elsajátíttatásának, azaz a külvilágból eredő információk feldolgozásának megértésének, valamint az egyén saját igényei kifejezésének és érvényesítésének közege. Mozgássérültek számára segíti a reális önismeret kialakulását, a társaktól való megkülönböztetést, a szocializációt és az individualizációt.

A koncepcióban megfogalmazódnak a kognitív területet érintő célok, külön hangsúlyt kap a problémamegoldó gondolkodás, a sokrétü érdeklődés, a kreativitás erősítése, a találékonyság, a kezdeményezés képessége, a tudatosság, a kritikai készség, a kitartás, a célképzés, tervezés, önellenőrzés, önértékelés. A felfogás hangsúlyozza a céltudatos tanulást, az egyéni cselekvési terv összeállításának képességét. Aktivitásnak az érdeklődést, tervezést, a cselekvés akarását tartja, nem pusztán magát a mozgást. Kiemelkedő jelentőségü a 
megismerési funkció lehetőségeinek megtalálása. A mozgástanulást szorosan összekapcsolja a kognitív területek fejlődésével, egymás feltételeinek nevezi.

Az elemzésből adódóan állíthatjuk, hogy a koncepció elsődleges feladatának a nevelést tartja, a személyiség ösztönző sajátosságcsoportjának formálását, de az oktatás szerepe sem kérdőjeleződik meg, melyet a nevelésnek rendel alá, az aktivizálásra használja fel. A koncepció megfogalmazásában a konduktív nevelés céljai megegyeznek az általános pedagógia és az oktatási - nevelési folyamat céljaival. A különbség a célok eljutásáig elvezető módban rejlik. Hári Mária és munkatársai a konduktív nevelés céljairól megfogalmazzák, hogy „A konduktív pedagógia komplex, integrált nevelési rendszerének programja céljait tekintve azonos az általános pedagógiáéval, ugyanis legfontosabb alapelve, hogy az általános oktatási-nevelési program céljait valósítsa meg; tehát nem az általános célokat kell módosítania, hanem a célok elérési módját kell megtanítania (Hári és tsai, 1991, 4. o.)”.

\section{A konduktív nevelési folyamat szabályozásának jellemzői}

A konduktív nevelési folyamat szabályozásában kiemelt jelentőséget kap a gyermeki aktivitás és a tevékenység irányításának kezelése. Az értelem fejlesztése a koncepció leírásaiban a mozgástanulással szorosan összefüggésbe kerül, mivel a folyamatos alkalmazkodáshoz célirányos, egyéni terv alapján összerendezett komplex tevékenységre van szükség, mely kialakítja a permanens tanulás igényét.

A felfogás nagy jelentőséget tulajdonít a képességnek megfelelő egyre önállóbb egyéni feladatvégzésnek, tevékenységnek, kezdve a célképzéstől, a tervezéstől, a cselekedeten át, az önellenőrzésig, mely végigvonul az egész nevelési folyamaton. Ezt hangsúlyozza Hári és Ákos is, akik így írnak erről: „A konduktív pedagógia azonban a tanulást nem korlátozza bizonyos foglalkozásokra, hanem az egész napra, annak minden tevékenységére kiterjeszti (Hári és Ákos, 1971, 133. o.)".

A nevelési folyamat szabályozásában meghatározó szerepe van a konduktornak, a kortárs csoportnak és a köztük létrejövő interakciónak.

A koncepció lényegesnek tartja a pedagógus közvetett és közvetlen hatásrendszerének müködtetését, a mintaadást, modellközvetítést és szokásalakítást. A gyermekek részéről a minta követését, befogadását, utánzását, majd ezekből kifejlődve az ortofunkciósokra jellemző spontenaitás kifejlődését.

A konduktív nevelési koncepció olyan magatartás és tevékenységformák kialakítását határozza meg, melyek aktivitásra ösztönöznek, illetve amelyeknek alapja az aktivitás. Ez elengedhetetlen a mozgássérültek passzivitásból való kimozdításához.

Az aktivitás kialakítására és fenntartására a feladatok és feladatsorok végeztetése mellett, a tanult mozgások alkalmazására és a megfelelő magatartásminták rögzítésére széles tevékenységrepertoárt biztosít a neveltek számára. A koncepció azt mondja ki, hogy a mozgássérült gyermeknek is minden életkorának megfelelő tevékenységben részt kell vennie. A fentiek alapján, figyelemmel a kritériumrendszerre azt rögzithetjük, hogy a koncepció a nevelési folyamatfelfogása szabályozottsága szerint irányitott, bázisa szerint aktivitásra épülö.

\section{A konduktív nevelés hatását biztosító tényezők rendszere}

A nevelési folyamatot befolyásoló tényezők közül ki kell emelni a tárgyi környezetet és feltételrendszert. A konduktív nevelésnek saját bútorai és eszközei vannak, melyek a tanulási folyamatot segítik, hozzájárulnak az aktivitás kialakításához, mozgásra késztetnek. 
Ezekre a bútorokra és eszközökre jellemző a praktikusság, a multifunkció, a stabilitás. Lényeges tulajdonságnak mutatkozik, hogy könnyen tolhatóak, egymásba rakhatóak, áthelyezhetöek, így az egyes csoportok kis helyen is elférnek.

A terek viszonylag nagyok, a mozgáshoz szükséges eszközök miatt. Minden helyiség saját mosdóval, mellékhelységgel, terasszal rendelkezik. A csoportszobák világosak, mindegyikben játék vagy pihenősarok található nyitott polcokkal, hozzáférhető játékokkal. A mozgássérült tanulási folyamata állandó figyelmet és rengeteg energiát igényel. Felhívja a figyelmet a koncepció a pihenés, a pihentető foglalkozások és a rendszeres munka helyes arányának megválasztására, a kimerülés elkerülésére.

A környezet, a helyiségek, a bútorzat és eszközök a nevelés eszközének tekinthetőek. Mindezek rendben, tisztán tartása, megörzése alapfeltétel, melyre a gyermeket rá kell nevelni.

A nevelési folyamatra ható tekintélyi személyek a konduktor és a szülök. A konduktív nevelés irányítása, tervezése és szervezése a konduktorok, a konduktori team feladata. Közösséget alakít ki, kapcsolata van a csoport tagjaival és azoknak egymás közötti kapcsolatát is irányítja.

A koncepció hangsúlyos szerepet szán a családdal való együttmüködésnek, ezt a gyermek személyiségfejlesztésének elengedhetetlen alapjának tartja. Célja a szülök szemléletváltása, a gyermek fejleszthetőségében való hit kialakítása, a családi nevelés megfelelő irányba terelése, reális célok, elvárások kialakítása. A család már a kezdetektől a nevelési folyamat aktív részesévé válik. A kapcsolat alapjának a kölcsönös bizalmat, koordinált kapcsolatot, felelősségérzetet, őszinteséget, korrekt tájékoztatást tartja. A család a nevelési folyamat részese, a tanultak otthoni alkalmazásában, megkövetelésében, az aktív életvitel otthoni kialakításában jelentős a szerepe.

A hatásszervezés szempontjából a folytonosságot biztosítja, mely elengedhetetlen a leépülés, visszaesés elkerülése miatt. Itt kell megemlítenünk, hogy a koncepció megfogalmazza, hogy ebben sem hagyja magára a családokat, találkozások, megbeszélések alkalmával közösen alakítják, ki az otthoni reális és megvalósítható aktív napirend lehetőségeit. Jó példa továbbá, hogy a szülőknek, felnőtteknek és a pedagógusoknak biztosított a folyamatos konzultáció, a rendszeres megbeszélés akár egy aktuális problémát, akár egy váratlan helyzetet, akár egy nevelési módszert tekintve.

Ez a folyamatos bizalmon alapuló kapcsolattartás kiterjed a már elbocsátott gyermekekre és családjukra is.

A konduktor szerepe közvetítő, alakító, rávezető, formáló funkció, aktív kapcsolatot alakít ki, támogató szerepet tölt be. „A konduktor szenvedélyes, humoros, mulattató, fantáziadús. Sokat számítanak a kondukcióban: dinamizmusa, arckifejezése, érzelmei, öröme (Hári és tsai, 1991, 32. o.)".

A nevelési tényezők közül a konduktív nevelési felfogás a kortársak és kortárscsoportok hatását alapfeltételnek mondja. A koncepció azt fogalmazza meg, hogy az aktív tanulás megvalósítása elsősorban csoportban lehetséges és szükséges. A társadalomból, közösségből való kiemelés kudarc, amitől a gyermeket meg kell kímélni. A közösségi életből a mozgássérülteket kizárni ezért nem szabad (Hári és tsai, 1991).

A felfogás kiemeli az egyéni szempontok maximális figyelembevételének fontosságát. Kihangsúlyozza, hogy ez akkor is megvalósítható, ha a gyermekek egyszerre dolgoznak. Nem szelektál képességszintek alapján, szervezetileg nem differenciál, hanem az egyéni differenciálást emeli ki. Azt mondja, a közös munka szervezését kell úgy megtervezni, hogy az egyéni képességek érvényesülhessenek.

A konduktív nevelési folyamat meghatározó tényezője a feladat és az ebből felépülő feladatsor, mely a mozgásfunkciók kialakítását tanítja. Az algoritmikusan felépített feladatsorok a tanulási folyamat részeként segítik a naponta ismétlődő feladatok által a tanult 
mozgásfunkciók beépülését a cselekvéssorokba, majd alkalmazását más tevékenységformákban.

„A feladatsorokon keresztül mintákat tanítunk, hogyan lehet megoldani egy mozgásmintát a sérülés tüneteinek leküzdésével. A konduktív pedagógia feladatsorai azoknak a feladatoknak a megoldását tanítják meg, amelyeket az ép gyermekek spontán megtanulnak. Ha pedig a dysfunctiós felnőtt, aki elveszítette számos régen elsajátított képességét, akkor a konduktív pedagógia a feladatsorok révén teszi lehetővé ezek újra megtanulását (Hári és Ákos, 1971, 136. o.)". A feladatsorok feladatai azonosak mindenki számára, azonban a megoldások, a rávezetés alkalmazott módjai, valamint a végrehajtásra tervezett időtartam és ritmus eltérő lehet. „A feladatsorok révén végül a dysfunctiósok magát a legáltalánosabb értelemben vett feladatmegoldást is megtanulják. Megtanulják a feladatok megértését és kitartóvá válnak a megoldások keresése, valamint a célok elérése közben. Ez már az általános nevelési célok szempontjait érinti. Az általános koordinációs képesség is kiterjed az információk legszélesebb körére, a felvetődő problémák felismerésére, a megoldáshoz vezető eljárások kialakítására (gondolkodásra), beszéd és tevékenység egybehangolására, a tudatos cselekvésre (Hári és Ákos, 1971, 143-144. o.)".

A feladatsorok és a tevékenységek kapcsolata szoros összefüggést mutatnak a napirend folyamatában. Erre az összefüggésre Hári és Ákos könyvében egyértelmű magyarázatot olvashatunk, mely a következőképpen hangzik: „A feladatsorok megoldása közben egyre gyakrabban sikerül orthofunctiós helyzeteket találni és orthofunctiós megoldásmódokat látni. A konduktor a napirend többi részében mindent elkövet ezeknek az orthofunctiós mozzanatoknak a felidézésére és beleépítésükre a tevékenységbe. Így javul az általános teljesítményszint, s az újonnan kialakított megoldások megszilárdulnak (Hári és Ákos, 1971, 141.o.)".

A szakirodalom elemzése során lényeges elemnek mutatkozott a hatásszervezés szempontjából, hogy a konduktív nevelés széles tevékenységrepertoárt biztosít a gyermekek számára, ahol a tanult mozgásfunkciók gyakorlása, alkalmazása történik az életkornak megfelelő szituációkban: óvodai élet tevékenységei, iskolai élet tevékenységei, hagyományok, ünnepek, intézményen kívüli elfoglaltságok (kirándulás, mozi, uszoda), szabadidős tevékenységek, játék, munka, tanulás, különböző szakkörök, önkiszolgálási tevékenységek, életmód program és adaptív sporttevékenységek.

A tevékenységek esetében rögzíthetjük, hogy a kialakult mozgás, az új koordináció alkalmazása mellett további funkciója az egészséges életmódra nevelés, esztétikai nevelés, intellektuális nevelés, mindemellett lehetőséget biztosít a szokásalakításra, a megfelelő modellek közvetítésére, a megfelelő magatartás- és viselkedésformák megerősítésére, illetve leépítésére.

További tényező a csoport, ami a konduktív nevelés szervezeti kerete és egyben célja is, mely a pedagógiai és pszichológiai hatásai mellett a mozgássérült gyermekek individualizációját, szocializálódását, azaz perszonalizációját készíti elő. Mind a gyermek, mind a szülei egy összetartó közösség tagjaivá válnak, úgy érzik, már nincsenek egyedül a problémájukkal. „Nem egy gyermeknek a feladatok megoldásához még a konduktor irányítására van szüksége. A gyermekek segítenek a konduktornak és egymásnak, ilyenformán baráti kapcsolatok szövődnek. A társas relációk kibontakoztatása a csoportban nem kevésbé fontos, mint az orthofunctiósok esetében (Hári és Ákos, 1971, 129. o.)".

A koncepció már az 1950-es években kiemeli a közösség szerepét, mindamellett, hogy az elfogadott fejlesztés sokáig individuálisan történt. Kiemelik a szerzők, hogy közösségben a mozgássérült biztonságban érzi magát, másképp cselekszik a társai között. (Mozgásterápiai Intézet és Tanszék Munkaközössége, 1957; Képzés tananyaga, 1965; Hári és Ákos, 1971; Hári és tsai, 1991) 
Még további tényező az aktív napirend, mely átfogja az egész napot. A sérülésből adódóan a mozgássérült élete lelassul, fejlődése elakad. A napirend ezért tartalmaz minden életkornak megfelelő tevékenységi formát mozgásállapotnak és értelemnek, biológiai és társadalmi elvárásoknak megfelelően. A napirend segít eligazodni a mindennapi tevékenységek rendszerében, biztonságot ad és a kitüzött reális feladatok által aktivitásra ösztönöz, lehetőséget ad a tanulásra és a tanultak alkalmazására. További szempontnak jelenik meg az aktív életmódra nevelés tekintetében, hogy a napirend rendet visz a gyermek életébe, hozzászoktatja a rendszeres tevékenységhez, rendszerességhez szoktat.

„A napirend tehát a követelmények egységes rendszere. Ezt a rendszert legvilágosabban pedagógiailag lehet jellemezni. Áthatja az időbeosztás rendszeressége, amely a normál életre oly jellemző és fontos dinamizmusra, az élet tempójára való nevelési célt alkot (Hári és Ákos, 1971, 134. o.)". Ehhez keretet a napirend biztosit, melynek minden perce hasznos, aktív tanulási folyamat. A koncepció megfogalmazása alapján a pedagógiailag üresjáratot kerülni kell, mert az a negatív lelki állapotnak kedvez.

A koncepció leírásában a természetes gyógymódok beépítése szintén jelentős a hatásszervezés szempontjából, része az egészséges életmódra nevelésnek, a mozgásra nevelés szempontjából. A koncepcióban megfogalmazottak alapján az elért eredmények fenntartásához - mivel mozgássérültekről van szó, akik sok esetben a négy fal közé szorulnak - a mai napig is elengedhetetlen a levegözés, a napfény jótékony hatása, a reggeli edzés, az egészséges táplálkozás és a megfelelö vitaminok szedése. A koncepció része volt, míg a neveltek nagyobb része bentlakásos ellátásban részesült, a nyitott ablakoknál ,, bepakolva”vastagon betakarva - alvás, a meleg vizes vagy zsályateás fürdö, mely feszes izomtónusú gyermekek esetén segitheti a lazulást.

A konduktív nevelés időtartama a törvényeknek megfelelöen a tanév rendjének megfelelően történik, bejáró rendszerben, napköziotthonos formában. Az iskolás korosztálynak szükség esetén bentlakó, illetve kollégiumi ellátást biztosít.

\section{A konduktív nevelés speciális módszerei}

A konduktív nevelés a mozgássérültek csoportban, egyidőben történő tanulásszervezésénél a differenciálás és a facilitálás széles tárházát használja fel. A feladatok ugyan azonosak, de a megoldásmódok minden esetben egyénre szabottak.

Elsődleges a neveltek megfigyelése, képességeik megismerése és ebből kiindulva a reális, megvalósitható, életkornak megfelelö rövid és hosszútávú célok megfogalmazása. A megfigyelés az egész nevelési folyamatot végigkíséri.

Egyedülálló módszere a ritmikus intendálás. A ritmikus intendálás egyfajta rákoncentrálás a feladatra, vagyis arra mit csinálok és hogyan csinálom, ennek a verbalizálása és időzítése. „A konduktor a feladatsor megszerkesztésekor a csoport tevékenységi szintjéhez igazodik, s az egyénenként meglevő különbségek figyelembevételével éri el, hogy a kitűzött célt mindenki megvalósítsa. Éppen ebben a folyamatban: a feladat megértetésével és eredményes megoldatásával válik az megtanulható, orthofunctiósan elvégezhető tevékenységgé (Hári és Ákos, 1971, 138. o.)”.

A konduktív nevelési folyamat nagy hangsúlyt fektet a gyermekek nevelésében a tudatosításnak és az önellenőrzésnek. A mozgás újbóli kialakításának és automatizálódásának feltétele a tudatosítás, vagyis annak a megértése, hogy az adott mozgás elvégzése miért is fontos, hol tudja hasznosítani, alkalmazni, miért is érdemes megtanulnia. Az önellenőrzés funkciója a mozgás és az elvégzett cselekvés megvalósulásának a kontrollja. 
A tudatositás és az önellenörzés a feladatmegoldás elengedhetetlen része, visszacsatolás a gyermek részére a feladatmegoldás helyességéröl. Segíti az aktivitás kialakítását, a sikerélmény biztosítását, az elhatározás létrejöttét, azaz az érzelmi fejlődét. Megtanítja a nevelteknek az általános elvárásokat, azoknak a megfelelő alkalmazási lehetőségeit. Ez a konduktív nevelésben a mozgástanításra is kiterjed. A kialakult új szokások, megtanult mozgásminták alkalmazása motiválóak, a környezet megismerését teszik lehetővé, sikerélményt biztosít a mozgássérültek életében. A belsővé vált minták tehermentesítik az agyat és teret nyitnak más életkornak megfelelő tevékenység megismerésére.

Az önfejlesztő képességek kialakításához az ellenőrzés, önellenőrzés, mintaadás, utánzás, értékelés módszereit tanítja a gyermekeknek. A gyermek a tudatosítás által megtanulja saját mozgását, a mozgás szavakkal való összekapcsolását, megtanulja a saját cselekvését értelmezni. A nevelési folyamat értékelésénél a jó megoldások megerösítésére és ezáltal az önellenőrzés tanítására helyezi a hangsúlyt, mely a helyes önértékelés és reális önkép kialakítását segíti. Nem utolsó szempontként jelenik meg, hogy a gyermeket megszégyeníteni nem szabad.

A tudatosításra és az önellenőrzés tanítására a konduktív nevelés széles tárházzal rendelkezik, például: az értékelést mindig konkrét célhoz, feladathoz kapcsolja, ezáltal visszacsatolva a feladatmegoldásra; a mozgásfeladatokat megismétli, az értékelés gyermek általi megfogalmazását kéri, a gyermekek egymást tanítják, ellenőrzik, a feladatmegoldást célmegfogalmazás előzi meg, tükröt használ, vizuális kontrollt alkalmaz, a ritmikus intendálást, a pozitív mintaadást, a sikerélményhez, eredményélményhez juttatja a gyermeket.

\section{A konduktív nevelés cél- és hatásrendszerének összefüggései}

A konduktív nevelés évtizedek alatt kifejlesztette azokat a jellegzetességét adó tényezőket, melyekbe integrálta az általános pedagógia elméletét és gyakorlatát, a különböző diszciplínák - orvostudomány, pszichológia, gyógypedagógia, filozófia - tapasztalatait, a természetes gyógymódok elemeit.

A konduktív nevelés a mozgássérültet egészként nézi. A koncepció ezt azzal indokolja, hogy az idegrendszer sérülése összetett tünetegyüttest eredményez, ami az egyén minden életfunkciójára kihat, ezért egészként kell kezelni. A mozgássérültek nevelése ezért csak holisztikus módon történhet hatékonyan és eredményesen. A célok, feladatok és az ebből kirajzolódó követelmények szintén egységet alkotnak, egy egységes rendszer részei. $A$ tünetegyüttes összetettsége a nevelési folyamatot is összetetté teszi.

A nevelési folyamat lefolyása szempontjából lényeges, hogy átlássuk kit, mire, miért, hogyan szeretnénk nevelni (lásd: 3. táblázat). A konduktív nevelés a központi idegrendszeri sérülés azon elemeit állítja a nevelés fókuszába, melyek pedagógiai megközelítést igényelnek, mint például a motiváció, az érdeklödés, az aktivitás, az érzelmi biztonság hiánya, csökkenése, a fáradékonyság, motoros minta, testkép, a mozgáskoordináció zavara. A konduktív nevelési folyamat célja a tanulási motiváció kialakítása, az aktivitás elérése és fenntartása, a tanulás módjainak és lehetőségeinek megtanítása, és ami ennél is fontosabb a megtanultak alkalmazása eltérő tevékenységekben, szituációkban. Alapelv a sérülésből adódó hátrányos következmények csökkentése, vagy ellensúlyozása. 


\begin{tabular}{|c|c|c|}
\hline \multicolumn{3}{|c|}{ A konduktív nevelés } \\
\hline Mit? & Miért? & $\begin{array}{l}\text { Hogyan? } \\
\text { (Hatásegyiittesek-nevelési tényezők) }\end{array}$ \\
\hline $\begin{array}{l}\text { Mozgás } \\
\text { akarása } \\
\text { (célirányos } \\
\text { mozgás, } \\
\text { intenció) }\end{array}$ & $\begin{array}{l}\text { passzivitás elkerülése, } \\
\text { tapasztalatszerzés, érzékelés, percep- } \\
\text { ció fejlesztése, megismerési funkciók } \\
\text { kialakítása, érzelem, akarati funkciók } \\
\text { fejlesztése, készenléti állapot elérése } \\
\text { és fenn-tartása, érzelmi biztonság } \\
\text { kia-lakítása, érdeklődés kialakítása és } \\
\text { fenntartása }\end{array}$ & $\begin{array}{l}\text { gyermek közösség, pedagógus } \\
\text { közösség, nevelési módszerek, } \\
\text { motiváció, intenció, célképzés, } \\
\text { életkornak megfelelö követel- } \\
\text { mények, példamutatás, eszközök, } \\
\text { bútorzat, aktív napirend felállítása, } \\
\begin{array}{l}\text { aktivitásra késztető, inspiráló } \\
\text { környezet }\end{array}\end{array}$ \\
\hline $\begin{array}{l}\text { Mozgás/ } \\
\text { cselekvés }\end{array}$ & $\begin{array}{l}\text { új minta, koordináció beépülése, } \\
\text { tanulása, automatizálódás, } \\
\text { sikerélmény, mozgásöröm, önbiza- } \\
\text { lom kialakítása,eredményélmény, }\end{array}$ & $\begin{array}{l}\text { egyéni és csoportos feladat, } \\
\text { feladatsor, természetes gyógymó- } \\
\text { dok,mintaadás, ellenőrzés, önel- } \\
\text { lenőrzés, tudatosítás, facilitálási } \\
\text { módok, rávezetés, ritmikus } \\
\text { intendálás, differenciálás, }\end{array}$ \\
\hline $\begin{array}{l}\text { Szisztematikus } \\
\text { alkalmazás, } \\
\text { aktív } \\
\text { viselkedés }\end{array}$ & adaptálás & $\begin{array}{l}\text { életkornak megfelelö tevékeny- } \\
\text { ségek (óvodai-, iskolai-, játék-, } \\
\text { munka-tevékenység, tanulás, önel- } \\
\text { látási és szabadidős tevékenység, } \\
\text { adaptív sport, néptánc, sakk stb.), } \\
\text { speciális programok (grafomotoros, } \\
\text { Lexi, Sindelar stb.) }\end{array}$ \\
\hline Ortofunkció & $\begin{array}{l}\text { önálló, hasznos részvétel, életmód, } \\
\text { célszerü funkciók, cselekvő részvétel } \\
\text { környezethez alkalmazkodás }\end{array}$ & $\begin{array}{l}\text { életvitel program, adaptív sport } \\
\text { integráló, esélyteremtő csoportok }\end{array}$ \\
\hline
\end{tabular}

A nevelési folyamat a meglévő képességekre épít. A koncepció hangsúlyozza, hogy az agy új kapcsolatok kialakítására képes. A helyreállítás feltételeként az életkornak megfelelő követelmények támasztása, a komplex fejlesztés, a célképzés tanítása, a rávezetés a követelmények saját erőböl történő kielégítésére, továbbá a tanulás optimális lehetőségeinek, az aktív elsajátításnak a biztosítása, végezetül ezek megfelelő strukturálása, a nevelés tervezése jelenik meg. A konduktív nevelés célmeghatározása alapján a megzavart tanulási folyamatot kell helyreállítani, megfelelö részcélok közvetítésével, komplex tevékenységek rendszerén keresztül (Hári és tsai, 1991).

A nevelés céljai közt nem csak azok a célok kapnak hangsúlyt, melyek az egyén általános társadalmilag elfogadott létéhez szükségesek, hanem azok a célok is, melyek az egyén képességeinek kibontakoztatását célozzák. Elsődleges célként jelenik meg a céltudatos tanulás, egyéni cselekvési terv, intenció - a mozgás akarásának - kialakítása. Ez összefüggésbe hozható a sérülés tünetegyütteséböl adódó passzivitással, kiszolgáltatottság érzésével. Ennek leépítése és értelmes, elérhető célok biztosításával a szándék kialakítható. A közösség és a benne zajló folyamatok, a pedagógus-gyermek-család megfelelö kapcsolata, a speciális napirend alapfeltétel a társadalmi integráció előkészítéséhez.

Ezt követi a különböző mozgásfeladatsorok által egy felfedezö-kialakító tanulási folyamat, ami létrehozza magát a mozgást. Ehhez a konduktív nevelés a sajátos módszerei, 
feladatsorai, speciális programjai biztosítják a keretet. Az újonnan kialakított mozgás koordinációt, automatizált cselekvést a tevékenységek széles körében alkalmazva tanulja meg a sérült adaptálni az eltérő feltételekhez aktív viselkedést eredményezve. A koordinálatlan mozgásból így alakul ki az ortofunkció. Végső cél a társadalmi integráció elérése, melyhez a keretet az életmód program, az integráló és esélyteremtő csoportok, az adaptív sport biztosítják.

Az előbbiekből egyértelműen kirajzolódik, hogy a konduktív nevelés céljai a mozgássérülés összetettségéből adódóan az érintett területek összesére irányul. Nem csak a mozgás fejlesztése a cél, az a kiindulópontja a nevelésnek és ezáltal a hatásszervezés szempontjából is az első lépcsőfok. De mellette a beszéd, az értelmi és érzelmi képességek, a szociális képességek fejlesztése is folyamatos. Megjelenik az ösztönző sajátosságcsoport fejlesztése, ami a nevelés elsődleges célja, de mellette párhuzamosan fejlesztésre kerülnek a különböző képességterületek, melyek lehetöséget biztosítnak a különböző ismeretek, jártasságok, készségek és képességek megszerzésére. A nevelés elsődleges szerepe megmutatkozik mind a kitüzött célokban, mind a hatásszervezésben, mely a személyiség diszfunkciós sajátosságainak leépítésére és az ortofunkciós sajátosságok kialakítására irányul. Az oktatási feladatokat egyértelmüen a nevelésnek rendeli alá, mivel a tanult mozgásokat különböző életkornak megfelelő tevékenységben alkalmaztatja, mely alkalmaztatás a mozgás adaptálását biztosítja. Nem utolsó szempont, hogy mindamellett, hogy létrejön az ortofukció, maga az aktív viselkedés pozitivan visszahat az érzelmekre, sikerélményt biztosit, erösíti az önbizalmat, ezáltal a folyamat ismétlésére ösztönöz és további újabb mozgások, cselekvések megtanitására ösztönöz. Ez folyamatosságot, az aktivitás fennmaradását biztositja, a folyamatos tanulás igényét formálja.

A nevelési folyamat egységessége szempontjából szintén meg kell említeni a személyi feltételt. A különböző területek fejlesztését nem a különböző szakemberek egymás utáni tevékenységében látja biztosítottnak, hanem a konduktor személyében, aki végig jelen van, folyamatosan és következetesen irányítja és szervezi a nevelési folyamatot.

A konduktív nevelési folyamatban a különböző hatótényezők, egymást kiegészítve, összefonódva, érvényesülnek. Fontos kérdés, hogy ezek a tényezők hogyan alakítják a személyiséget, hogyan fejtik ki hatásukat, hogyan hatnak a viselkedés alakulására? A konduktív nevelési folyamatban az eddig elemzettek alapján kijelenthetjük, hogy a nevelési folyamatban mind a környezeti, mind a pedagógia tényezőknek jelentőséget tulajdonít. A nevelési folyamat elemzése során arra következtethetünk, hogy a koncepció a magatartásformálás összetett hatásrendszerében nem részesít egyetlen tényezőt sem elsőbbrendünek, a tényezők egységes rendszerét és együttes hatását hangsúlyozza. Az egyes tényezők ugyanolyan fontosnak mutatkoznak, hatásegyüttesként fejtik ki hatásukat. Az egyes hatásegyüttesek sem szeparáltan fejtik ki hatásukat, hanem egymást erősítve, esetleg kioltva. A hatásegyüttesek látszólag globális folyamat- és hatásszervezésre utalnak, de a koncepció kiemeli az egyéniség, az egyéni sajátosság figyelembevételének létfontosságát. A hatásegyüttesek az egyes neveltek szempontjából hasonlóságot mutatnak, mégsem azonosak. A hatásszervezés szempontjából a differenciálást alapfeltételnek határozhatjuk meg. Szemlélete emberközpontú, amely a neveltekhez való pozitív érzelmi viszonyban, egy nyitott, humánus, érzelmi biztonságot nyújtó légkört teremtve valósul meg. Az integráció és a szocializációs folyamatok elősegítésére a különböző képességterületek sajátos nevelési és oktatási folyamatban történő fejlesztése életkorspecifikus - korai fejlesztés, óvodai és iskolai élet - tevékenységekbe ágyazottan történik a köznevelési rendszer részeként köznevelési feladatokat lát el. Az integráció szolgálatában a nevelési rendszer óvodai integráló csoportok és az iskolai esélyteremtö csoport müködését is beiktatta rendszerébe, mely az iskolán kiegészül az életmód programmal. 
A tanulmányban elemzett folyamatok, a nevelési tényezők és hatásaik párhuzamba állíthatóak a konduktív nevelés céljaival. A nevelés a központi idegrendszeri sérülésböl és tüneteiből adódó diszfunkciók és tevékenységek egységet képeznek.

\section{Irodalom}

Bábosik, I. (1999). A nevelés elmélete és gyakorlata. Budapest: Nemzeti Tankönyvkiadó.

Bábosik, I. (2004). Neveléselmélet. Nevelés az Európai Unióban. Budapest: Osiris Kiadó.

Balogh, E. \& Kozma, I. (2000). Cerebralis Paresis. In Kálmánchey, R. (Ed.), Gyermekneurológia (pp.139-154) Budapest: Medicina Kiadó.

Balogh, M. (1998, Ed.). Bevezetö a konduktivv mozgáspedagógiába. Petö András elöadási és gyakorlati bemutatói alapján. 2. bővített kiadás. Budapest: MPANNI.

Báthory, Z. (1997). Tanulók, iskolák - különbségek. Egy differenciális tanitáselmélet vázlata (pp.119-157). Második átdolgozott kiadás. Budapest: Okker Kiadó.

Benczúr, M. (2000). A mozgáskorlátozott gyermekek szomatopedagógiai nevelése az óvodában és az iskolában. In Illyés, S. (Ed.), Gyógypedagógiai alapismeretek (pp. 535560) Budapest: ELTE-BGGYFK.

Hári, M. \& Ákos, K. (1971). Konduktív pedagógia. Első kötet. Budapest: Tankönyvkiadó.

Hári, M. (1981). Konduktív pedagógia II. Az orthofunkció kialakítása. 4. szám. Budapest: Copyright.

Hári, M. (1982). Konduktív pedagógia II. Az orthofunkció kialakítása. 5. szám. Budapest: Copyright.

Hári, M. (1990a). A konduktív nevelés története, fogalmai. In Első Konduktív Pedagógiai Világkonferencia (pp. 9-14) Budapest: MPANNI.

Hári, M. (1990b). A konduktív pedagógiai rendszer. Budapest: Nemzetközi Pető Intézet.

Hári, M., Horváth, D., Kozma, Gy., Kőkuti, M. (1991). A konduktív pedagógiai rendszer hatékony müködésének alapelvei és gyakorlata. Budapest: Nemzetközi Pető Intézet.

Hári, M. (1997). A konduktív pedagógia története. Budapest: MPANNI.

Hári, M. (2000): Konduktív nevelés az óvodában és az iskolában. In: Illyés, S. (Ed.), Gyógypedagógiai alapismeretek, (pp. 561-571). Budapest: ELTE-BGGYFK.

Kotschy, B. (2003). Az oktatás célrendszere. In. Falus, I. (Ed.), Didaktika - Elméleti alapok az tanitás tanulásához, (pp. 107-134). Nemzeti Tankönyvkiadó Rt.

Képzés tananyaga. I. témacsoport. Kondukció alapjai (1965). Mozgássérültek Nevelőképző és Nevelöintézete.

Kullmann, L. (2006). Az orvosi rehabilitáció sajátosságai. In Huszár, I.; Kullmann, L. \& Tringer L. (Ed.), A rehabilitáció gyakorlata (pp. 13-21) Budapest: Medicina Könyvkiadó Rt.

Örkényiné Deák, A. (1997) Az ortofunkció alkalmazása. Segédanyag az azonos c. tárgyhoz. Jegyzet. Budapest: MPANNI.

Mihály, O. (1974). Nevelésfilozófia és pedagógiai célelméletek. Budapest: Akadémiai Kiadó.

Mihály, O. (1998). Bevezetés a nevelésfilozófiába. Budapest: Okker Kiadó.

Mozgásterápiai Intézet és Tanszék Munkaközössége (1957). Mozgásterápiai Tájékoztató. Budapest: Gyógypedagógiai Tanárképző Főiskola.

Papavasiliou, A. \& Panteliodis, C.P. (2011). Clinical characteristics. In: Panteliadis, C.P. (Ed.), Cerebral palsy. A multidisciplinary approach. (pp. 89-105). Munich - Orlando: Dustri-Verlag.

Pető, A. (1953). Szovjet mozgásterápiai módszerek. In A magyar gyógypedagógia a nervizmus szemléletében. Budapest: Tankönyvkiadó. pp. 47-51. 
Pető, A. (1955). A konduktív mozgásterápia mint gyógypedagógia. In: Gyógypedagógia Vol. 1 (1). pp. 15-21

Réthy, E. (2002). A speciális szükségletü gyermekek nevelése, oktatása Európában: Az integráció és az inklúzió elméleti és gyakorlati kérdései. In: Magyar Pedagógia, 102. évf. 3. sz. pp. 281-300.

Schüttler, V. (2002). Az inklúzív oktatás fenntartása: a speciális oktatást igénylő gyermekek bevonása a többségi iskolákba. Budapest: OKI.

Vekerdy-Nagy, Zs. (2010, Ed.). Rehabilitációs orvoslás. Budapest: Medicina Könyvkiadó Zrt.

\section{Internetes hivatkozások}

Borosán, L. \& Busi, E. (2004.). Pedagógiai Személyiségértelmezések. Apertus Közalapítvány. Letöltés ideje: 2018. 03. 27.

Web: http://edutech.elte.hu/multiped/ped_02/ped_02.pdf

Cans C., Dolk H., Platt M.J., et al. (2007). Recommendations from the SCPE collaborative group for defining and classifying cerebral palsy. SCPE Collaborative Group. Developmental medicine and child neurology. Supplement. Feb; 109:35-8

Letöltés ideje: 2017. 01. 20.

Web: http://onlinelibrary.wiley.com/doi/10.1111/j.1469-8749.2007.tb12626.x/pdf

Rosenbaum, P., Paneth, N., Leviton, A. et al (2007). The Definition and Classification of Cerebral Palsy. Developmental Medicine \& Child Neurology. february, Volume 49, Issue Supplements109, Pages 2-43

Letöltés ideje: 2017. 01. 20.

Web:http://www.fizjoterapeutom.pl/attachments/article/348/Bax_M_2007_The_Definition_a nd_Classification_of_Cerebral_Palsy.pdf 